\title{
Compressive Strength Prediction of Ferrochrome Slag Based Geopolymer Concretes Produced Under Different Curing Conditions by Using Prediction Methods
}

\section{Tahmin Metotları Kullanılarak Farklı Kürr Koşullarında Üretilen Ferrokrom Cürufu Esaslı Geopolimer Betonların Basınç Dayanım Tahmini}

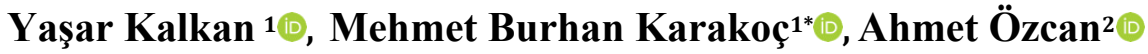 \\ 1 Inönü University, Faculty of Engineering, Department of Civil Engineering, Malatya, TÜRKIYE \\ ${ }^{2}$ Kütahya Dumlupınar University, Faculty of Engineering, Department of Civil Engineering, Kütahya, TÜRKIYE \\ Sorumlu Yazar / Corresponding Author*: mehmet.karakoc@inonu.edu.tr

\begin{abstract}
In this study, compressive strength (CS) values of ferrochrome slag (FS) based geopolymer concretes in different curing conditions were investigated. Ground FS was activated with the mixture of sodium hydroxide and sodium silicate. The silica modulus $\left(\mathrm{M}_{\mathrm{s}}\right)$ of the geopolymer concrete samples were selected as $1.25,1.50$ and 1.75 . Also, samples were prepared by substituting $0 \%, 10 \%$ and $20 \%$ silica fume (SF) replacement the FS. Thus, 9 groups geopolymer concrete samples were produced. The CS values of the samples were determined on different curing times $\left(24,48,72\right.$ and 96 hours) and curing temperatures $\left(23,40,60,80\right.$ and $\left.100{ }^{\circ} \mathrm{C}\right)$. At the same time, multilayer perceptron neural network (MLPNN), extreme learning machine neural network (ELMNN) and M5 model tree were modeled for the CS prediction of the samples, the predict and experimental results were compared. According to the experiment results, it was determined that the CS values generally increased as the curing time increased, but with the addition of SF, the CS values generally decreased. The highest CS was obtained in the sample containing $100 \% \mathrm{FS}$ that had silica modulus of 1.25 and cured at $100{ }^{\circ} \mathrm{C}$ for $24-48-72$ or 96 hours. The $\mathrm{R}^{2}$ values of MLPNN, ELMNN and M5 model tree in testing phase were 0.956, 0.935 and 0.922 , respectively. MLPNN, the model that gave the best predict result, had root mean square error (RMSE) of 0.723 and normalized root mean square error (NMRSE) of 26.485 in testing.
\end{abstract}

Keywords: Geopolymer concrete, Ferrochrome slag, Curing condition, ELMNN, MLPNN, M5 model tree

Öz

Bu çalışmada farklı kür koşullarındaki ferrokrom cürufu (FS) esaslı geopolimer betonların basınç dayanımı (CS) değerleri incelenmiştir. Öğütülmüş FS sodyum hidroksit ve sodyum silikat karışımı ile aktive edilmiștir. Geopolimer beton numunelerinin silis modülü $\left(\mathrm{M}_{\mathrm{s}}\right) 1.25,1.50$ ve 1.75 olarak seçilmiștir. Aynı zamanda FS yerine \%0, \%10 ve \%20 oranlarında silis dumanı (SF) ikame edilerek numuneler hazırlanmıştır. Böylece 9 grup geopolimer beton numunesi üretilmiştir. Farklı kür 
sürelerinde $\left(24,48,72\right.$ ve 96 saat) ve kür sıcaklıklarında $\left(23,40,60,80\right.$ ve $\left.100{ }^{\circ} \mathrm{C}\right)$, numunelerin CS değerleri belirlenmiştir. Aynı zamanda, numunelerin CS tahmini için çok katmanlı algılayıcı sinir ağı (MLPNN), aşırı öğrenme makinesi sinir ağı (ELMNN) ve M5 model ağacı modellenmiştir, tahmin ve deney sonuçları karşılaştırılmıștır. Deney sonuçlarına göre, kür süresi arttıkça genellikle CS değerleri artmıştır, fakat SF ilavesi arttıkça, CS değerleri genellikle azalmıștır. \%100 FS içeren, silis modülü 1.25 olan ve $24-48-72$ veya 96 saat $100^{\circ} \mathrm{C}^{\prime}$ de kür edilen numunede en büyük CS elde edişmiştir. Test aşamasındaki MLPNN, ELMNN ve M5 model ağacının R2 değerleri sırasıyla 0.956, 0.935 ve 0.922 'dir. En iyi tahmin sonucunu veren MLPNN'nin test aşamasındaki ortalama karakök hatası (RMSE) 0.723 ve normalleştirilmiş kök ortalama kare hatası (NMRSE) 26.485'tir.

Keywords: Geopolimer beton, Ferrokrom cürufu, Kür koşulları, ELMNN, MLPNN, M5 model ağacı

\section{Introduction}

Geopolymers have attracted great interest in construction and engineering areas due to their excellent mechanical properties, low shrinkage value, high fire resistance and low energy consumption. Geopolymers are produced at ambient temperatures or at high temperatures by mixing aluminosilicate-containing materials such as fly ash, blast furnace slag with alkaline activations. These hazardous wastes are preferred because of their low cost, low $\mathrm{CO} 2$ content and environmental friendliness [1] Geopolymer is a type of aluminosilicate binder material which formed by the thermal activation of alkali metal hydroxide and silicate solution with solid aluminosilicate based materials such as fly ash, metakaolin, ground blast furnace slag. These binders are of interest due to their potential use, such as being a sustainable alternative to Portland cement and their high performance and environmental friendliness [2]. Geopolymers are inorganic polymer materials. Geopolymerization is a chemical reaction between alumina-silicate oxides and alkali metal silicate solutions in high alkali conditions. The strength of geopolymers also depends on the quality of the source materials. These natural raw materials are fly ash, metakaolin and slag. They show higher compressive strength (CS) than kaolin clay materials [3].

Silico ferrochrome and ferrochrome slag (FS) are waste materials generated by the production of electric-arc furnaces in the plants where ferrochrome production is performed When the chemical composition of FS is examined, it is seen that four main elements dominate. These were silicon, magnesium, aluminum and calcium. These elements constitute approximately $95 \%$ of the slag as oxides. In addition, there is very little iron and chrome. There is not organic matter in the slag [4]. In the literature, there are studies on the durability [5-10] and compressive strength [1112] changes of geopolmer concrete produced using ferrorchrome slag depending on the alkali activator types. However, information about curing conditions and times are insufficient.

Some of the researchers stated that as the amount of $\mathrm{NaOH}$ increased, the compressive strength of the geopolymers increased, while others reported the opposite. The reasons for this contrast are (i) the high viscosity deterioration of $\mathrm{NaOH}$ solution by reason of leaky $\mathrm{Al}$ and $\mathrm{Si}$ ions due to high concentration, (ii) excessive $-\mathrm{OH}$ concentration causing early collapse of geopolymer gels, (iii) partial reaction of incompletely dissolved $\mathrm{Si}$ and $\mathrm{Al}$ species. Heat treatment is required for geopolymers to achieve similar or higher compressive strength than Portland cement concretes. Thanks to the heat treatment, the geopolymerization and dissolution of the aluminosilicate gel is provided. This causes the geopolymer to gain early high strength. It also accelerate the dissolution of silica and alumina species and then the polycondensation process [13]. High temperatures do not always have a positive effect on compressive strength. At higher curing temperature, the dissolution rate of silica and alumina increases and gel polycondensation accelerates. When the temperature is too high, the rapid polycondensation of the geopolymeric gel and the rapid evaporation of water reduces the compressive strength of the geopolymer by preventing silica and alumina completely dissolving [14].

Neural networks based prediction methods have become popular in recent years and have been used by researchers in many different 
engineering fields. It is a family of largely parallel architectures that solve difficult problems through collaboration of neural networks. Neural networks are similar to brain neurons and its processing elements consist of many simple computing elements arranged in layers. The logic of the developed neural network based model to determine the behavior of the material is to train the neural network according to the experiment results of the material. If the experimental results contain information on material behavior, the trained neural network will contain sufficient information for the material model. In this way, both the results of the experiments can be increased and the results in other experiments can be approached with the ability to generalize [15].

Hadi et al. (16) predicted the CS values of fly ash based geopolymer mortars with artificial neural networks (ANN). Bondar [17] used multilayer ANN to estimate the strength of natural alumina silica based geopolymers. Kamallo et al. [18] used three layer ANN to estimate CS values of metacaolin-based geopolymers. Deepa et al [19] used multilayer perceptron (MLP), MP5 tree models and Linear Regression algorithms to predict the CS of high performance concrete. Nazari and Torgal [20] used six different ANN models to predict the CS of different types of geopolymers. Yadollahi et al. [21] used ANN to predict the CS of geopolymer composites. Yadollahi et al. [22] predicted the CS of geopolymer composites using adaptive network-based fuzzy inference systems (ANFIS), two linear and nonlinear regression models. Yaseen et al. [23] predicted the CS of lightweight foamed concretes using extreme learning machine (ELM) and M5 tree models. Nadiri et al. [24] used hybrid fuzzy model to predict the CS of Alumina-Silica-based geopolymers. Al-Shamiri et al. [25] used ELM and ANN to predict the CS of high-strength concrete. Dao et al. [26] predicted the CS of geopolymer concretes with ANFIS and ANN.

This paper aims to construct models to evaluate the effect of adding SF, silica modulus, curing temperature and curing time on CS of FS based geopolymer concrete. The methods used for estimation were extreme learning machine neural network (ELMNN), multilayer perceptron neural network (MLPNN) and M5 model tree. In this study, FS based geopolymer concrete samples were produced and these samples were added $0 \%, 10 \%$ and $20 \%$ silica fume (SF). Geopolymer concrete mixes using three different $(1.25,1.50$ and 1.75$)$ silica modulus (Ms) were produced. The samples were cured at four different temperatures (23, $40,60,80$ and $\left.100^{\circ} \mathrm{C}\right)$ and 4 different times $(24$, 48,72 and 96 hours) and the CS of the samples were examined. At the same time, the CS values of the samples were predicted by using ELMNN, MLPNN and M5 model tree, and compared with the experimental results. 9 different geopolymer concrete mixtures that were produced in this study were modeled, trained and tested using MATLAB.

\section{Material and Method}

\subsection{Material}

\subsubsection{Ferrochrome slag}

FS was supplied from Elazı̆ ferrochrome plants. The supplied ferrochrome slag consisted of large and small grains. But $90 \%$ of the grains were smaller than $2 \mathrm{~mm}$. In order to increase the reactivity of FS with alkaline activators, the slag was grounded and slag that passed $45 \mu \mathrm{m}$ sieve were used for the geopolymer concrete mixtures. The chemical composition of FS is given in Table 1.

\subsection{Silica fume}

Specific gravity of SF was $2.35 \mathrm{~g} / \mathrm{cm}^{3}$. SF was provided from the Antalya Electrometallurgy Plant. $0 \%, 10 \%$ and $20 \%$ SF were used in geopolymer concrete mixtures. The chemical composition of SF is given in Table 1.

\subsection{Alkaline activators}

Sodium hydroxide and sodium metasilicate as alkali activators were used. The color of the two activators is white. The density of sodium hydroxide and sodium silicate is 2.13 and 1.38 g/cm ${ }^{3}$, respectively. $\mathrm{Na}_{2} \mathrm{O}, \mathrm{SiO}_{2}$ and $\mathrm{H}_{2} \mathrm{O}$ contents of sodium silicate are 8.9, 27.5 and $63.6 \%$, respectively.

\subsection{Aggregate}

River sand as fine aggregate and river gravel as coarse aggregate were used in the geopolymer concrete mixtures. The aggregate used in the experiments was natural river material and was washed prior to use. 
Table 1. Oxide compositions of FS and SF

\begin{tabular}{lrrrrrrrrrrrr}
\hline Component (\%) & $\mathrm{SiO}_{2}$ & $\mathrm{Al}_{2} \mathrm{O}_{3}$ & $\mathrm{Fe}_{2} \mathrm{O}_{3}$ & $\mathrm{CaO}$ & $\mathrm{MgO}$ & $\mathrm{Cr}_{2} \mathrm{O}_{3}$ & $\mathrm{SO}_{3}$ & $\mathrm{Na}_{2} \mathrm{O}$ & $\mathrm{K}_{2} \mathrm{O}$ & $\mathrm{TiO}_{2}$ & $\mathrm{Cl}$ & $\begin{array}{r}\mathrm{Free}^{2} \\
\mathrm{SiO}_{2}\end{array}$ \\
\hline $\mathrm{FS}$ & 33.8 & 25.48 & 0.61 & 1.1 & 35.88 & 2.12 & - & - & - & - & - & - \\
$\mathrm{SF}$ & 91.8 & 0.35 & 3,91 & 0.48 & 0.62 & - & 0.16 & 0.38 & 0.68 & $<0.01$ & 0.06 & 1.93 \\
\hline
\end{tabular}

\subsection{Method}

\subsubsection{Experimental program}

The flowchart of the preparation, curing conditions, experimental and prediction methods of the geopolymer concrete is given in Figure 1. Geopolymer concrete mix amounts are
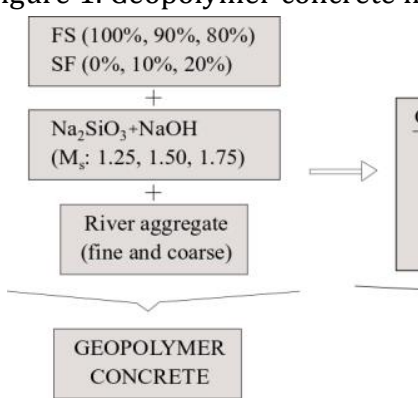

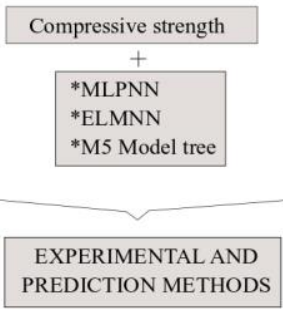

Figure 1. The flowchart of the preparation, curing conditions, experimental and prediction methods of the geopolymer concrete

given in Table 2. The prepared geopolymer concrete mixture were molded with $50 \times 50 \times 50$ $\mathrm{mm}^{3}$ and $40 \times 40 \times 160 \mathrm{~mm}^{3}$ steel molds. CS values of geopolymer concrete samples were tested according to ASTM C39/C39M-18 [27]. For each group, three specimens were tested and averaged.

\subsubsection{Prediction methods \\ 2.2.2.1. Extreme learning machine neural network}

In practical applications, ELM is trained first and then prediction process is done. During the training process, influence factors and the related results are placed in the ELM for training through an iteration to complete the learning process [28]. Unlike traditional learning algorithms, ELMNN tends to reach not only the smallest educational error but also the smallest norm of weight [29]. Recently, an ELM has been proposed to train a single hidden layer feedforward neural network. In ELMNN, hidden nodes are randomly initialized and then detected without being iteratively set. In fact, the hidden nodes in ELMNN don't even have to be neurons. The only free parameter to be learned is the connections (or weights) between the hidden layer and the output layer. Thus, ELMNN is formulated as a linear model that curtails the solution of a linear system. Compared with traditional feedforward artificial neural networks learning methods, ELMNN is highly effective and tends to reach a global optimum level [30].

The data is modeled with the ELMNN model using a simple three-step construction procedure as follows: (i) randomly generating hidden layer weights and deviations; (ii) propagating inputs along hidden layer parameters to produce the hidden layer output matrix; and (iii) estimating the output weights 
DEÜ FMD 23(69), 881-891, 2021

Table 2. Amount of material used in the mixture $\left(\mathrm{kg} / \mathrm{m}^{3}\right)$

\begin{tabular}{|c|c|c|c|c|c|c|c|c|c|c|}
\hline & & ES0 & ES1 & ES2 & ES0 & ES1 & ES2 & ES0 & ES1 & ES2 \\
\hline \multicolumn{2}{|c|}{$\begin{array}{l}\text { Silica modulus } \\
\left(M_{s}\right)\end{array}$} & \multicolumn{3}{|c|}{1.25} & \multicolumn{3}{|c|}{1.50} & \multicolumn{3}{|c|}{1.75} \\
\hline FS & & 400 & 360 & 320 & 400 & 360 & 320 & 400 & 360 & 320 \\
\hline SF & & 0 & 40 & 80 & 0 & 40 & 80 & 0 & 40 & 80 \\
\hline $\mathrm{Na}_{2} \mathrm{SiO}_{3}$ & & 181.82 & 181.82 & 181.82 & 218.22 & 218.22 & 218.22 & 254.61 & 254.61 & 254.61 \\
\hline $\mathrm{NaOH}$ & & 15.36 & 15.36 & 15.36 & 13.27 & 13.27 & 13.27 & 11.18 & 11.18 & 11.18 \\
\hline Water & & 38.4 & 38.4 & 38.4 & 33.18 & 33.18 & 33.18 & 27.95 & 27.95 & 27.95 \\
\hline \multirow{2}{*}{ Aggregate } & $\begin{array}{l}0-4 \\
\mathrm{~mm}\end{array}$ & 1130.27 & 1125.04 & 1119.8 & 1095.72 & 1090.48 & 1085.22 & 1061.21 & 1055.96 & 1050.71 \\
\hline & $\begin{array}{l}4-8 \\
\mathrm{~mm}\end{array}$ & 515.8 & 513.4 & 511.01 & 500.02 & 497.62 & 495.23 & 484.26 & 481.87 & 479.48 \\
\hline
\end{tabular}

by inverting the hidden layer output matrix using the Moore-Penrose generalized inverse matrix, and then calculating its product with the response variable. This process requires the random sorting of hidden neurons after the identification of hidden neuron nodes. For a series of d-dimensional vectors defined for $\mathrm{i}: 1$, $2, \ldots, \mathrm{N}$ training samples, $\mathrm{L}$ hidden neurons and single hidden layer feedforward neural networks are mathematically expressed as follows [23].

$$
f_{L}(x)=\sum_{i=1}^{L} h_{i}(\mathrm{x}) \beta_{i}=h(\mathrm{x}) \beta
$$

Here $\beta=[\beta 1, \beta 2 \ldots \beta \mathrm{L}] \mathrm{T}$ is the output weight matrix between hidden neurons and output neurons, $h(x)=[h 1, h 2 \ldots h L]$ are hidden neuron outputs representing random hidden properties of the $x i$ predictor, $\mathrm{hi}(\mathrm{x})$ is the ith hidden neuron [23].

The parameter values determined for the ELMNN in this study are as follows:

Number of input neuron: 7

Number of hidden neuron: 10

\subsubsection{Multilayer perceptron neural network}

Multilayer perceptron (MLP) is one of the most commonly used feedforward ANN types for nonlinear function approach tasks [31]. MLP is a neural network with multiple layers and neurons. The basic principle of a neural network is inspired by the human brain, in which neurons receive input signals and process output signals. Each neuron is connected with at least one neuron and the linkage is evaluated using the weight coefficient. A neuron has a universal predictive power. MLP is the extension of a simple neural network from one hidden layer to more than one hidden layer. As the layers and neurons increase, the network structure becomes more complex than a simple neural network and thus can solve nonlinear problems. The structure of the MLP with two hidden layers can be written as follows [32]:

$f(x)=B_{3}+W_{3} f\left(B_{2}+W_{2} f\left(B_{1}+W_{1} x\right)\right)$

$W_{1}, W_{2}, W_{3}$ represents the weight matrix, $B_{1}, B_{2}$, $B_{3}$ represents the threshold. $f$ remains a nonlinear function. More hidden layers and neurons help improve the accuracy of the network, especially for nonlinear problems [32].

\subsubsection{M5 model tree}

This model is mainly based on a binary decision tree that has a series of linear regression functions in leaf nodes. The main purpose of the model defines the relationship between dependent and independent variables [33]. The M5 algorithm is used to inducing a model tree. Assume that the training examples have a $\mathrm{T}$ collection. Each instance is characterized by the values of a constant (input) attribute set and has an associated target (output) value. The aim is to create a model that correlates the target value of educational cases with the values of input attributes. The quality of the model will usually be measured with accuracy in which invisible cases estimate target values. Treebased models are created by a division and conquest method [34]. The M5 model tree was first introduced by Quinlan (1992). Model trees, 
such as regression trees, are effective for large data sets. First, the M5 model trees algorithm creates a regression tree by iteratively dividing the sample area. The split condition is used to minimize subset variability in values from the root through the branch to the node. It is measured by the standard deviation of the values that reach the node from the root branch by calculating the expected reduction in error as a result of each attribute tested in this node. An attribute is selected as to maximizes the expected line reduction. If the output values of all the samples reaching the node change slightly or only a few samples remain, the division is terminated [35]. Root mean square error (RMSE), normalized root mean square error (NMRSE) and the coefficient of determination (R2) are calculated as follows [36]:

$$
\begin{aligned}
& R M S E=\sqrt{\frac{1}{N} \sum_{n=1}^{N}\left(A_{n}-P_{n}\right)^{2}} \\
& N R M S E=\frac{R M S E}{S} \\
& R^{2}=1-\frac{\sum\left(A_{n}-P_{n}\right)^{2}}{\sum\left(A_{n}-S_{n}\right)^{2}}
\end{aligned}
$$

where

$A_{n}$ : actual value

$P_{n}$ : predicted value

$N$ : Number of data points

\section{$S$ : Average of actual values}

The models to predict the CS values of FS based geopolymer concrete in this study are produced. For this aim, at first it is needed to prepare data and construct databases for training and testing the models. Pruned model tree is given below. The M5 model tree structure is given in Figure 2. The parameter values determined for the M5 model tree in this study are as follows:

- Number of rules: 5

- Number of original input variables used: 4 (x3, x4, x5, x7)

- Execution time: 0.10 seconds

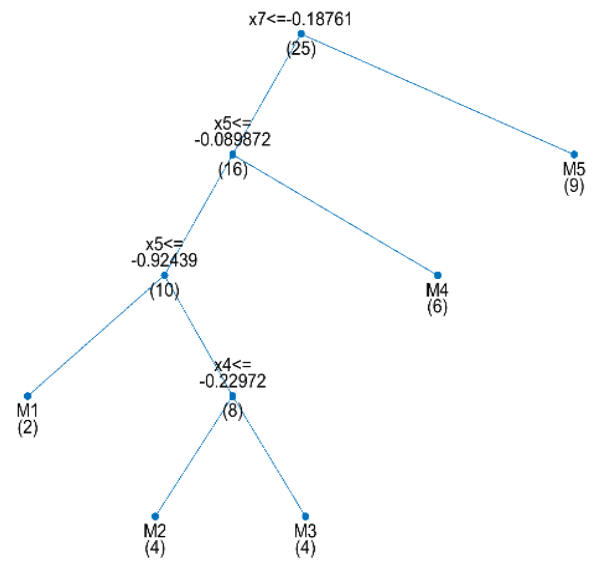

Figure 2. M5 model tree structure

\section{Results and Discussions}

\subsection{Experiment results}

CS values of FS based geopolymer concretes produced in different curing conditions and containing SF are given in Table 3. The highest CS was seen in geopolymer concretes containing $100 \% \quad F S$ and had 1.25 silica modulus and were cured in 24, 48, 72 and 96 hours at $23{ }^{\circ} \mathrm{C}$. When the $\mathrm{CS}$ values of the samples were examined, it was seen that the average CS values of the samples decreased as the silica modulus increased. But curing temperatures effects were not clear in the samples that had 1.50 or 1.75 silica modulus. Görhan and Kürklü [37] concluded that as the curing temperature increased, the CS increased, but this did not a significant effect on the physical properties. Vijai et al. [38] stated that the increases in CS values of fly ash based geopolymer concretes which were cured in oven were less than the increases in samples without oven curing. Atiş et al. [39] determined the highest CS value (120 MPa) in a fly ash based geopolymer mortars cured at $115{ }^{\circ} \mathrm{C}$ for 24 hours. The highest CS value (120 MPa) was gotten at geopolymer samples cured at $115{ }^{\circ} \mathrm{C}$ for 24 hours. Swanepoel and Strydom [40] produced fly ash and kaolin based geopolymer paste samples. These samples were cured at 40 , 50,60 and $70{ }^{\circ} \mathrm{C}$ for $6,24,48$ and 72 hours and the CS values of the samples were determined. Optimum conclusion was obtained in the samples that were cured 48 hours at $60{ }^{\circ} \mathrm{C}$. Okoye et al. [41] stated that CS of the geopolymer concrete increased till curing 
temperature reached up to $100{ }^{\circ} \mathrm{C}$, but it decreases at $120^{\circ} \mathrm{C}$ curing temperature.

The CS of the sample containing 100\% FS which were cured at $100{ }^{\circ} \mathrm{C}$ for 96 hours was 20.23 MPa while the CS of the $10 \%$ SF added sample cured which were cured at $100{ }^{\circ} \mathrm{C}$ for 96 hours was $17.48 \mathrm{MPa}$. While the silica modulus was 1.25 , the CS values of the samples were negatively affected at temperatures higher than $23{ }^{\circ} \mathrm{C}$ and increasing curing times. However, when the silica modulus were 1.50 and 1.75 , there was a significant increase in the CS of SFfree samples at increased curing temperatures and curing times. The SF additive generally caused a decrease in the CS of the samples. Volumetric changes occurred due to swelling and cracking in samples containing SF along with increasing curing temperature. Therefore, the CS values of these samples was lower than SF-free samples.

\subsection{Predicted results}

Relationships between MLPNN, ELMNN and M5 model tree predicted results and experimental results are given in Figure 3. $\mathrm{R}^{2}$ values for training of MLPNN, ELMNN and M5 model tree prediction results were $0.990,0.925$ and 0.958 , respectively. R2 values for testing of MLPNN, ELMNN and M5 model tree prediction results were 0.956, 0.935 and 0.922, respectively. RMSE, NRMSE and correlation values of the prediction methods for training and testing are given in

Tables 4-5. When the correlation values of the prediction methods were examined, MLPNN gave better results than the other two prediction methods. In Figure 4, experimental results with MLPNN, ELMNN and M5 model tree prediction results are given. When the values in the graphs in Figure 3 were examined, it was seen that the predicted results were quite close to the experimental results.

Table 4. Comparison of errors of different models (for training)

\begin{tabular}{lccc}
\hline Methods & RMSE & NRMSE & $\mathrm{R}^{2}$ \\
\hline MLPNN & 0.358 & 11.696 & 0.990 \\
ELMNN & 0.828 & 27.376 & 0.925 \\
M5 model tree & 0.621 & 20.275 & 0.958 \\
\hline
\end{tabular}

Table 5. Comparison of errors of different models (for testing)

\begin{tabular}{lccc}
\hline Methods & RMSE & NRMSE & $\mathrm{R}^{2}$ \\
\hline MLPNN & 0.723 & 26.485 & 0.956 \\
ELMNN & 0.899 & 32.564 & 0.935 \\
M5 model tree & 0.830 & 30.368 & 0.922 \\
\hline
\end{tabular}


DEÜ FMD 23(69), 881-891, 2021

Table 3. CS (MPa) values of geopolymer concretes

\begin{tabular}{|c|c|c|c|c|c|c|c|}
\hline \multirow[t]{2}{*}{ Mixture } & \multirow{2}{*}{$\begin{array}{r}\text { Silica } \\
\text { modulus }\left(\mathrm{M}_{\mathrm{s}}\right)\end{array}$} & \multirow{2}{*}{$\begin{array}{r}\text { Time } \\
\text { (hours) }\end{array}$} & \multicolumn{5}{|c|}{ Temprature $\left({ }^{\circ} \mathrm{C}\right)$} \\
\hline & & & 23 & 40 & 60 & 80 & 100 \\
\hline \multirow[t]{4}{*}{ ES0 } & 1.25 & 24 & 21.53 & 13.85 & 16.35 & 17.48 & 17.23 \\
\hline & & 48 & 21.53 & 15.08 & 16.78 & 17.55 & 17.78 \\
\hline & & 72 & 21.53 & 15.08 & 17.23 & 17.85 & 18.60 \\
\hline & & 96 & 21.53 & 15.76 & 17.98 & 19.40 & 20.23 \\
\hline \multirow[t]{4}{*}{ ES1 } & 1.25 & 24 & 18.34 & 11.63 & 10.88 & 9.08 & 12.75 \\
\hline & & 48 & 18.34 & 12.05 & 11.25 & 11.03 & 14.85 \\
\hline & & 72 & 18.34 & 12.20 & 13.88 & 13.13 & 15.88 \\
\hline & & 96 & 18.34 & 13.23 & 15.80 & 14.68 & 17.48 \\
\hline \multirow[t]{4}{*}{ ES2 } & 1.25 & 24 & 16.53 & 11.73 & 13.93 & 9.73 & 10.50 \\
\hline & & 48 & 16.53 & 11.95 & 14.15 & 12.18 & 12.38 \\
\hline & & 72 & 16.53 & 13.23 & 14.70 & 12.68 & 13.30 \\
\hline & & 96 & 16.53 & 15.45 & 17.38 & 12.70 & 14.28 \\
\hline \multirow[t]{4}{*}{ ES0 } & 1.50 & 24 & 12.45 & 9.03 & 9.40 & 11.26 & 10.18 \\
\hline & & 48 & 12.45 & 9.50 & 13.30 & 12.90 & 15.00 \\
\hline & & 72 & 12.45 & 11.88 & 13.88 & 13.48 & 15.03 \\
\hline & & 96 & 12.45 & 12.48 & 15.93 & 14.73 & 16.63 \\
\hline \multirow[t]{4}{*}{ ES1 } & 1.50 & 24 & 13.48 & 11.60 & 12.25 & 10.48 & 11.20 \\
\hline & & 48 & 13.48 & 11.78 & 12.33 & 11.78 & 13.33 \\
\hline & & 72 & 13.48 & 12.40 & 15.18 & 12.13 & 14.63 \\
\hline & & 96 & 13.48 & 13.58 & 15.50 & 13.28 & 15.47 \\
\hline \multirow[t]{4}{*}{ ES2 } & 1.50 & 24 & 14.70 & 10.53 & 10.73 & 9.45 & 11.85 \\
\hline & & 48 & 14.70 & 10.80 & 11.20 & 10.35 & 12.20 \\
\hline & & 72 & 14.70 & 12.95 & 11.83 & 10.68 & 12.63 \\
\hline & & 96 & 14.70 & 12.68 & 11.90 & 12.63 & 12.78 \\
\hline \multirow[t]{4}{*}{ ES0 } & 1.75 & 24 & 7.60 & 11.93 & 9.40 & 9.30 & 9.90 \\
\hline & & 48 & 7.60 & 12.53 & 12.13 & 10.23 & 11.98 \\
\hline & & 72 & 7.60 & 13.03 & 14.83 & 10.60 & 13.18 \\
\hline & & 96 & 7.60 & 14.13 & 15.43 & 10.75 & 13.00 \\
\hline \multirow[t]{4}{*}{ ES1 } & 1.75 & 24 & 10.20 & 8.75 & 10.47 & 8.10 & 8.55 \\
\hline & & 48 & 10.20 & 8.90 & 10.53 & 9.53 & 8.33 \\
\hline & & 72 & 10.20 & 9.00 & 11.88 & 9.67 & 8.70 \\
\hline & & 96 & 10.20 & 9.25 & 12.15 & 10.80 & 10.95 \\
\hline \multirow[t]{4}{*}{ ES2 } & 1.75 & 24 & 11.50 & 8.83 & 9.70 & 8.85 & 8.68 \\
\hline & & 48 & 11.50 & 8.88 & 9.90 & 9.63 & 9.33 \\
\hline & & 72 & 11.50 & 9.95 & 9.93 & 9.88 & 10.25 \\
\hline & & 96 & 11.50 & 10.56 & 10.68 & 10.13 & 10.73 \\
\hline
\end{tabular}

It is observed that $\mathrm{R}^{2}$ values in three methods (MLPNN, ELMNN, M5 model tree) used in the prediction of CS of FS based geopolymer concretes are higher than 0.92 . For this reason, researchers can gain both in terms of time and suitability by using these methods in CS predicts of geopolymer concretes. The most ideal model for both training and testing in terms of RMSE, NRMSE and $\mathrm{R}^{2}$ values was MLPNN. However, the other two methods were quite sufficient to predict the results. 
(a)

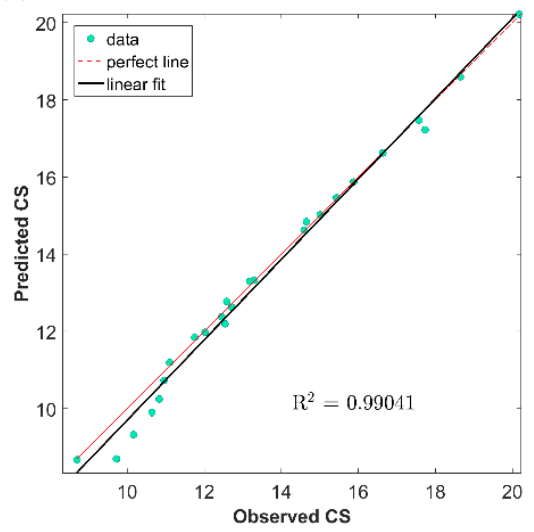

(b)

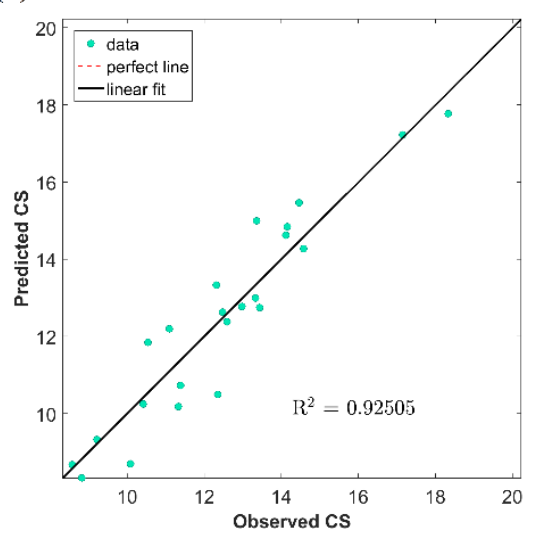

(c)

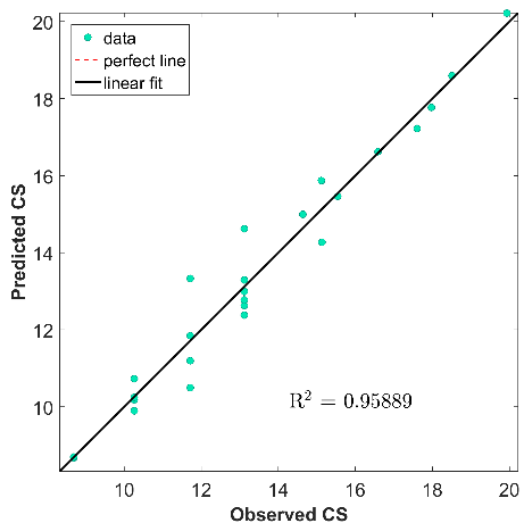

Figure 3. Distribution graph of experimental and predicted CS values in training; (a) MLPNN, (b) ELMNN, (c) M5 model tree (a)
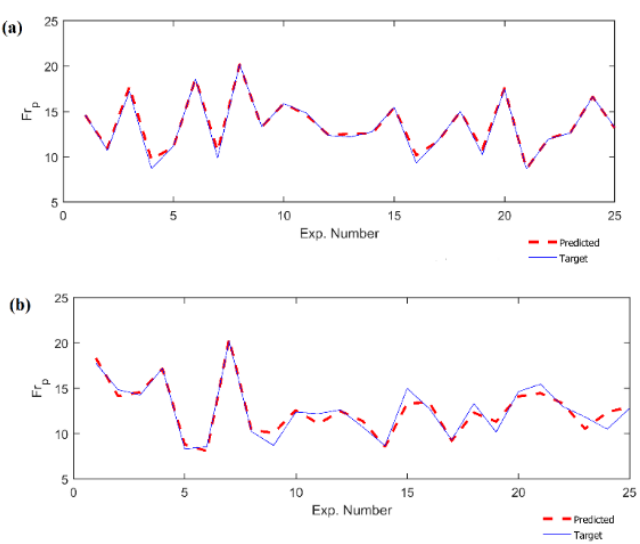

(c)

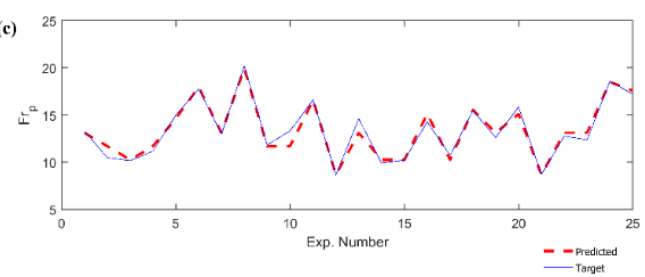

Figure 4. Comparison of experimental and predicted CS values in training; (a) MLPNN, (b) ELMNN, (c) M5 model tree

\section{Conclusions}

Results show that the CS values increase, as curing times of geopolymer concretes increased. As silica modulus of geopolymer concrete samples increased, the CS values of the samples decreased. The optimum value for the silica modulus was 1.25 . The CS values of geopolymer concretes generally decreased as the SF additive increase. MLPNN, ELMNN and M5 model tree algorithms were used to predict the CS of the samples produced under different curing conditions. FS ratio, SF ratio, curing temperature and curing time were chosen as input variables. The output variable was the CS of the sample. Because they had an accuracy rate greater than 0.92 in the three methods used in the CS prediction of the samples, these methods performed well in the CS prediction of the geopolymer concrete. The best result of these three methods was obtained in MLPNN. MLPNN had RMSE of 0.723, NMRSE of 26.485 and $\mathrm{R}^{2}$ of 0.956 in testing, RMSE of 0.358, NMRSE of 11.696 and $R^{2}$ of 0.990 in training. 
However, the other two methods were quite sufficient to predict the results.

\section{Acknowledgements}

The research work reported in this paper supported within the research project number of BAP 2015/77 by İnönü University, Scientific Research Project programme.

\section{References}

[1] Zhang, Y.J., Li, S., Wang, Y.C., Xu, D.L. 2012, Microstructural and strength evolutions of geopolymer composite reinforced by resin exposed to elevated temperature. Journal of Non-Crystalline Solids, 358, 620-624. DOI: 10.1016/j.jnoncrysol.2011.11.006

[2] Thakur, R.N., Ghosh, S. 2009, Effect of mix composition on compressive strength and microstructure of fly ash based geopolymer composites. ARPN Journal Engineering and Applied Sciences, 4(4), 68-74.

[3] Bakri, A.M.M.A., Kamarudin, H., Mohamed, H., Ruzaidi, C.M., Rafiza, A.R., Faheem, M.T.M., Izzat, A.M. 2011, Properties and microstructura characteristics of geopolymers using fly ash with different percentages of kaolin at room temperature curing, Australian Journal of Basic and Applied Sciences, 5(10), 824-828.

[4] Yılmaz, A., Sütaş, İ. 2008. Ferrokrom cürufunun yol temel malzemesi olarak kullanımı, İMO Teknik Dergi, 294, 4455-4470. (In Turkish)

[5] Yadollahi, M.M., Dener, M. 2019. Investigation of elevated temperature on compressive strength and microstructure of alkali activated slag based cements, European Journal of Environmental and Civil Engineering 1-15 DOI: 10.1080/19648189.2018.1557562

[6] Özcan, A., Karakoç, M.B. 2019. Evaluation of sulfate and salt resistance of ferrochrome slag and blast furnace slag-based geopolymer concretes, Structural Concrete, 20, 1607-1621. DOI: 10.1002 /suco.201900061

[7] Özcan, A., Karakoç, M.B. 2019. The resistance of blast furnace slag- and ferrochrome slag-based geopolymer concrete against acid attack, International Journal of Civil Engineering, 17, 15711583. DOI: $10.1007 / \mathrm{s} 40999-019-00425-2$

[8] Özdal, M., Karakoç, M.B., Özcan, A. 2019. Investigation of the properties of two different slag based geopolymer concretes exposed to freezethaw cycles, Structural Concrete, 1-9. DOI: 10.1002/suco.201900441

[9] Türkmen, İ., Karakoç, M.B., Kantarcı, F., Maraş, M.M. Demirboğa, R. 2016. Fire resistance of geopolymer concrete produced from Elazı̆ ferrochrome slag, Fire and materials, 40, 836-847. DOI $10.1002 /$ fam. 2348

[10] Karakoc, M.B., Türkmen, İ., Maras, M.M., Kantarcl, F., Demirboğa, R. 2016. Sulfate resistance of ferrochrome slag based geopolymer concrete, Ceramics International, 42, 1254-1260. DOI: 10.1016/j.ceramint.2015.09.058
[11] Karakoç, M.B., Türkmen, İ., Maraș, M.M., Kantarci, F., Demirboğa, R., Toprak, M.U. 2014. Mechanical properties and setting time of ferrochrome slag based geopolymer paste and mortar, Construction and Building Materials, 72, 283-292. DOI: 10.1016/j.conbuildmat.2014.09.021

[12] Nath, S.K. 2018. Geopolymerization behavior of ferrochrome slag and fly ash blends, Construction and Building Materials, 181, 487-494. DOI: 10.1016/j.conbuildmat.2018.06.070

[13] Ken, P.W., Ramli, M., Ban, C.C. 2015. An overview on the influence of various factors on the properties of geopolymer concrete derived from industrial byproducts, Construction and Building Materials, 77, 370-395. DOI: 10.1016/j.conbuildmat.2014.12.065

[14] Mohajerani, A., Suter, D., Jeffrey-Bailey, T., Song, T., Arulrajah, A., Horpibulsuk, S., Law, D. 2019. Recycling waste materials in geopolymer concrete, Clean Technologies and Environmental Policy, 21, 493-515. DOI: 10.1007/s10098-018-01660-2

[15] Öztaș, A., Pala, M., Özbay, E., Kanca, E., Çağlar, N., Bhatti, M.A. 2006. Predicting the compressive strength and slump of high strength concrete using neural network, Construction and Building Materials, 20, 769-775. DOI: 10.1016/j.conbuildmat.2005.01.054

[16] Hadi, M.N.S., Al-Azzawi, M., Yu, T. 2018. Effects of fly ash characteristics and alkaline activator components on compressive strength of fly ashbased geopolymer mortar. Construction and Building Materials, 175, 41-54. DOI: 10.1016/j.conbuildmat.2018.04.092

[17] Bondar, D. 2014. Use of a Neural Network to Predict Strength and Optimum Compositions of Natural Alumina-Silica-Based Geopolymers, Journal of Materials in Civil Engineering, 26(3), 499-503. DOI: 10.1061/(ASCE)MT.1943-5533.0000829

[18] Kamallo, A., Ganjkhanlou, Y., Aboutalebi, S.H., Nouranian, H. 2010. Modeling of compressive strength of metakaolin based geopolymers by the use of artificial neural network, International Journal of Engineering, Transactions A: Basics, 23(2), 145-152.

[19] Deepa, C., Kumari, S.K., Sudha, V.P. 2010. Prediction of the compressive strength of high performance concrete mix using tree based modeling, International Journal of Computer Applications, 6(5), 18-24. DOI: 10.5120/1076-1406

[20] Nazari, A., Torgal, F.P. 2013. Predicting compressive strength of different geopolymers by artificial neural networks, Ceramics International, 39, 2247 2257. DOI: $10.1016 / j . c e r a m i n t .2012 .08 .070$

[21] Yadollahi, M.M., Benli, A., Demirboğa, R. 2015. Prediction of compressive strength of geopolymer composites using an artificial neural network, Materials Research Innovations, 19(6), 453-458. DOI: $10.1179 / 1433075 X 15 Y .0000000020$

[22] Yadollahi, M.M., Benli, A., Demirboğa, R. 2017. Application of adaptive neuro-fuzzy technique and regression models to predict the compressive strength of geopolymer composites, Neural Computing and Applications, 28, 1453-1461. DOI: 10.1007/s00521-015-2159-6

[23] Yaseen, Z.M., Deo, R.C., Hilal, A., Abd, A.M., Bueno, L.C., Salcedo-Sanz, S., Nehdi, M.L. 2018. Predicting 
compressive strength of lightweight foamed concrete using extreme learning machine model, Advances in Engineering Software, 115, 112-125 DOI: 10.1016/j.advengsoft.2017.09.004

[24] Nadiri, A.A., Asadi, S., Babaizadeh, H., Naderi, K 2018. Hybrid fuzzy model to predict strength and optimum compositions of natural Alumina-Silicabased geopolymers, Computers and Concrete, 21(1), 103-110. DOI: 10.12989/cac.2018.21.1.103

[25] Al-Shamiri, A.K., Kim, J.H., Yuan, T.-F., Yoon, Y.S 2019. Modeling the compressive strength of highstrength concrete: An extreme learning approach Construction and Building Materials, 208, 204-219. DOI: 10.1016/j.conbuildmat.2019.02.165

[26] Dao, D.V., Ly, H.-B., Trinh, S.H., Le, T.-T., Pham, B.T 2019. Artificial intelligence approaches for prediction of compressive strength of geopolymer concrete, Materials, 12, 983. DOI $10.3390 / \mathrm{ma12060983}$

[27] ASTM C39/C39M-18 2018. Standard test method for compressive strength of cylindrical concrete specimens. ASTM International, West Conshohocken, PA. DOI: 10.1520/C0039_C0039M18

[28] Ding, S., Zhao, H., Zhang, Y., Xu, X., Nie, R. 2015 Extreme learning machine: algorithm, theory and applications, Artificial Intelligence Review, 44, 103 115. DOI: $10.1007 / \mathrm{s} 10462-013-9405-\mathrm{Z}$

[29] Huang, G.-B., Zhu, Q.-Y., Siew, C.-K. 2006. Extreme learning machine: Theory and applications, Neurocomputing, 70, 489-501. DOI 10.1016/j.neucom.2005.12.126

[30] Huang, G., Huang, G.-B., Song, S., You, K. 2015 Trends in extreme learning machines: A review, Neural Networks, 61, 32-48. DOI: 10.1016/j.neunet.2014.10.001

[31] Cabaneros, S.M., Calautit, J.K., Hughes, B.R. 2019. A review of artificial neural network models for ambient air pollution prediction, Environmental Modelling \& Software, 119, 285-304. DOI: 10.1016/j.envsoft.2019.06.014

[32] Tang, X., Zhang, L., Ding, X. 2019. SAR image despeckling with a multilayer perceptron neural network, International Journal of Digital Earth, 12(3), 354-374. DOI $10.1080 / 17538947.2018 .1447032$

[33] Mansouri, I., Ozbakkaloglu, T., Kisi, O., Xie, T. 2016. Predicting behavior of FRP-confined concrete using neuro fuzzy, neural network, multivariate adaptive regression splines and M5 model tree techniques, Materials and Structures, 49, 4319-4334. DOI: 10.1617/s11527-015-0790-4

[34] Bhattacharya, B., Solomatine, D.P. 2005. Neural networks and M5 model trees in modelling water level-discharge relationship. Neurocomputing, 63, 381-396. DOI: 10.1016/j.neucom.2004.04.016

[35] Naeej, M., Bali, M., Naeej, M.R., Amiri, J.V. 2013. Prediction of lateral confinement coefficient in reinforced concrete columns using $\mathrm{M}^{\prime}$ machine learning method, KSCE Journal of Civil Engineering, 17(7), 1714-1719. DOI: 10.1007/s12205-013-0214-

[36] Yaman, M.A., Elaty, M.A., Taman, M. 2017. Predicting the ingredients of self compacting concrete using artificial neural network, Alexandria Engineering Journal, 56, 523-532. DOI: 10.1016/j.aej.2017.04.007

[37] Görhan, G., Kürklü, G. 2014. The influence of the $\mathrm{NaOH}$ solution on the properties of the fly ash-based geopolymer mortar cured at different temperatures, Composites Part B: Engineering, 58, 371-377. DOI: 10.1016/j.compositesb.2013.10.082

[38] Vijai, K., Kumutha, R., Vishnuram, B.G. 2010. Effect of types of curing on strength of geopolymer concrete, International Journal of The Physical Sciences, 5(9),1419-1423. DOI:

[39] Atiș, C.D., Görür, E.B., Karahan, O., Bilim, C., İlkentapar, S., Luga, E. 2015. Very high strength $(120 \mathrm{MPa})$ class $\mathrm{F}$ fly ash geopolymer mortar activated at different $\mathrm{NaOH}$ amount, heat curing temperature and heat curing duration, Construction and Building Materials, 96, 673-678. DOI: 10.1016/j.conbuildmat.2015.08.089

[40] Swanepoel, J.C., Strydom, C.A. 2002. Utilisation of fly ash in a geopolymeric material, Applied Geochemistry, 17, 1143-1148. DOI: 10.1016/S08832927(02)00005-7

[41] Okoye, F.N., Durgaprasad, J., Singh, N.B. 2015. Mechanical properties of alkali activated flyash/kaolin based geopolymer concrete, Construction and Building Materials, 98, 685-691. DOI: 10.1016/j.conbuildmat.2015.08.009 